\title{
Pemberdayaan Kader Posyandu Dalam Upaya Skrining Kehamilan Melalui Pemeriksaan Kehamilan Sederhana di Desa Menganti Kabupaten Cilacap
}

\author{
Rochany Septiyaningsih ${ }^{1}$, Septiana Indratmoko ${ }^{2}$, Frisca Dewi Yunadi ${ }^{3}$ \\ STIKES Al Irsyad Al Islamiyyah Cilacap, \\ Email Korespondensi : rochany.septiyaningsih87@gmail.com
}

\begin{abstract}
Abstrak
Angka Kematian Ibu (AKI) menjadi indikator penting kemajuan suatu bangsa dan merupakan bentuk indikator keberhasilan suatu negara dalam memberikan pelayanan dan kesejahteraan kepada rakyatnya. Masalah gizi pada ibu hamil seperti anemia dan KEK juga berisiko terhadap bayi yang dikandungnya antara lain kematian janin (keguguran), prematur, lahir cacat dan bayi berat lahir rendah (BBLR). Adapun faktor yang memperberat keadaan ibu hamil seperti empat terlalu serta faktor yang mempersulit proses penanganan kedaruratan kehamilan, persalinan dan nifas seperti lebih kurang 65\% kehamilan yang terjadi berhubungan dengan 4 terlalu dan 3 terlambat. Peran kader posyandu dalam mengenali dan mendeteksi dini faktor risiko tinggi dalam kehamilan adalah dengan mendeteksi dini status gizi melalui pengukuran lingkar lengan atas (LILA), pengukuran kadar hemoglobin $(\mathrm{Hb})$ dan deteksi empat terlalu pada ibu hamil. Tujuan kegiatan ini diharapkan dapat meningkatkan pengetahuan dan ketrampilan kader posyandu melakukan skrining kehamilan melalui pemeriksaan kehamilan sederhana. Metode kegiatan ini adalah dengan penyuluhan tentang masalah gizi (anemia dan KEK) dan demonstrasi pemeriksaan sederhana kehamilan (Hb stik,LILA, empat terlalu). Hasil kegiatan ini adalah meningkatnya pengetahuan dan ketrampilan kader dalam melakukan pemeriksaan sederhana kehamilan (Hb dengan stik, LILA dan empat terlalu). Salah satu kader melakukan pemeriksaan pada 6 ibu hamil dan hasilnya semua ibu hamil dalam kondisi normal.
\end{abstract}

Kata kunci : gizi, kehamilan, anemia

\begin{abstract}
The Maternal Mortality Rate (MMR) is an important indicator of the progress of a nation and is an indicator of the success of a country in providing services and welfare to its people. Nutritional problems in pregnant women such as anemia and KEK are also at risk to their babies, including fetal death (miscarriage), premature birth defects and low birth weight babies $(L B W)$. There are factors that aggravate the condition of pregnant women such as four too much as well as factors that complicate the process of handling emergency pregnancy, childbirth and childbirth such as approximately $65 \%$ of pregnancies that occur related to 4 too and 3 late. The role of posyandu cadres in early recognition and detection of high risk factors in pregnancy is early detection of nutritional status through measurement of upper arm circumference (LILA), measurement of hemoglobin levels $(\mathrm{Hb})$ and detection of four too in pregnant women. The purpose of this activity is expected to increase the knowledge and skills of posyandu cadres in conducting pregnancy screening through simple pregnancy checks. The method of this activity is counseling on nutritional problems (anemia and KEK) and demonstration of simple pregnancy examinations ( $\mathrm{Hb}$ stick, LILA, four too). The result of this activity was the increased knowledge and skills of cadres in performing simple pregnancy examinations (Hb with sticks, LILA and four too). One of the cadres examined 6 pregnant women and the results were all pregnant women in normal condition.
\end{abstract}

Key words: nutrition, pregnancy, anemia 


\section{PENDAHULUAN}

Angka Kematian Ibu (AKI) menjadi indikator penting kemajuan suatu bangsa dan merupakan bentuk indikator keberhasilan suatu negara dalam memberikan pelayanan dan kesejahteraan kepada rakyatnya. Indonesia merupakan salah satu negara yang memiliki AKI relatif tinggi di dunia. Dari tahun 2007 AKI di Indonesia hanya 228 jiwa per 100.000 kelahiran hidup, namun angka tersebut meningkat di tahun 2012 menjadi 359 jiwa per 100.000 kelahiran hidup. AKI tersebut kembali turun di tahun 2015 menjadi 305 jiwa per 100.000 kelahiran hidup dan pada tahun 2018 AKI tersebut masih di angka 305 jiwa per 100.000 kelahiran hidup (Achadi, 2019).

Jawa Tengah merupakan wilayah provinsi di Indonesia yang AKI relatif tinggi, akhir tahun 2016 AKI di Jawa Tengah mencapai 116 per 100.000 kelahiran hidup, menempati posisi kedua di Indonesia pada saat itu. Pada tahun 2018 terjadi AKI di Jawa Tengah hingga 421 kasus (Jawa Pos, 2019). Salah satu kabupaten di Jawa Tengah yang memiliki persoalan tentang tingginya AKI adalah Kabupaten Cilacap. AKI di Kabupaten Cilacap tahun 2017 sebanyak 20 kasus, mengalami kenaikan pada tahun 2018 sebanyak 22 kasus.

Faktor yang menyebabkan kematian ibu secara garis besar dapat dikelompokkan menjadi penyebab langsung dan tidak langsung. Penyebab langsung kematian ibu adalah faktor yang berhubungan dengan komplikasi kehamilan, persalinan dan nifas seperti perdarahan, pre eklamsia, eklamsia, infeksi, persalinan macet dan abortus (Krisnadi, 2014).Salah satu penyebab perdarahan post partum adalah masalah gizi pada ibu hamil. Masalah gizi yang sering terjadi pada ibu hamil adalah anemia gizi besi dan Kekurangan Energi Kronik (KEK).

Ibu hamil dengan masalah gizi akan berdampak terhadap kesehatan dan keselamatan ibu. Kondisi ibu hamil KEK berisiko partus lama, perdarahan post partum bahkan kematian ibu karena adanya penurunan kekuatan otot yang membantu persalinan (Kementrian Kesehatan Republik Indonesia., 2015). Menurut (Adriani M dan Wirjatmadi B, 2016) selain menyebabkan perdarahan gizi kurang pada ibu hamil dapat menyebabkan anemia, berat badan ibu tidak bertambah secara normal, terkena penyakit infeksi dan dapat berpengaruh pada proses persalinannya yaitu persalinan sulit dan lama, terjadi persalinan sebelum waktunya (premature) dan meningkatkan kecenderungan persalinan dengan operasi. Berdasarkan data yang didapatkan prevalensi anemia pada ibu hamil diperkirakan di Asia sebesar 48,2\%, 
Afrika 57,1\%, Amerika 24,1\% dan Eropa 25,1\%. Prevalensi anemia pada ibu hamil di Indonesia meningkat dibandingkan dengan 2013, pada tahun 2013 sebanyak 37,1\% ibu hamil anemia sedangkan pada tahun 2018 meningkat menjadi 48,9\% (Riset Kesehatan Dasar (Riskesdas), 2018).

Masalah gizi pada ibu hamil seperti anemia dan KEK juga berisiko terhadap bayi yang dikandungnya antara lain kematian janin (keguguran), premature, lahir cacat dan bayi berat lahir rendah (BBLR). BBLR berpotensi mengalami masalah gizi sepanjang siklus kehidupan dan akan berulang pada generasi selanjutnya serta merupakan penyebab utama kematian bayi (Kementrian Kesehatan Republik Indonesia., 2015). Selain itu menurut Adriani dan Wirjatmadi (2016) KEK pada ibu hamil dapat menyebabkan keguguran, bayi lahir mati, kematian neonatal, anemia pada bayi dan asfiksia.

Penyebab kematian tidak langsung kematian ibu adalah faktor yang memperberat keadaan ibu hamil seperti empat terlalu serta faktor yang mempersulit proses penanganan kedaruratan kehamilan, persalinan dan nifas seperti lebih kurang 65\% kehamilan yang terjadi berhubungan dengan 4 terlalu dan 3 terlambat. Empat terlalu yaitu terlalu muda (usia kurang dari 20 tahun) menyebabkan 3\% kematian ibu di Indonesia, terlalu tua (usia lebih dari 35 tahun) menyebabkan 4,7\% kematian ibu di Indonesia, terlalu sering melahirkan (jarak kehamilan kurang dari 2 tahun) menyebabkan 5,5\% kematian ibu di Indonesia dan terlalu banyak anak (lebih dari 3 anak) menyebabkan 8,1\% kematian di Indonesia (Detik Health, 2019). Sedangkan 3 terlambat yaitu terlambat mengenali kehamilan dalam situasi gawat, jauh dari fasilitas kesehatan, biaya, persepsi mengenai kuantitas dan efektivitas dari pelayanan kesehatan. Terlambat kedua dipengaruhi oleh lama pengangkutan, kondisi jalan dan biaya transportasi. Faktor yang mempengaruhi terlambat ketiga adalah terlambat mendapatkan pelayanan pertama kali di RS rujukan (Krisnadi, 2014).

Faktor-faktor tersebut menjadi penentu kasus kematian ibu, sehingga membutuhkan peran kader posyandu untuk menemukan ibu hamil dan membantu bidan desa dalam mendeteksi dini persoalan kesehatan pada ibu hamil sehingga mampu memantau setiap ibu hamil dan mengantarkan pada persalinan ibu yang selamat dan bayi lahir sehat. Peran kader posyandu dalam mengenali dan mendeteksi dini faktor risiko tinggi dalam hal ini deteksi dini status gizi melalui pengukuran lingkar lengan atas (LILA), pengukuran kadar hemoglobin (Hb) dan deteksi empat terlalu pada ibu hamil sangat penting, karena kader posyandu merupakan bagian dari masyarakat itu sendiri yang dapat membantu meningkatkan status 
kesehatan masyarakat dari sisi promotif dan preventif. Kader posyandu akan dapat memberikan motivasi atau bahkan edukasi untuk ibu hamil risiko tinggi untuk rutin melakukan pemeriksaan kehamilan secara rutin. Untuk itu perlu dilakukan suatu pelatihan tentang pemeriksaan kehamilan sederhana yang dapat membekali kader posyandu dalam upaya skrining kehamilan.

Berdasarkan uraian permasalahan yang ada, dengan menerapkan bidang keilmuan kebidanan Perguruan Tinggi STIKES Al-Irsyad Al-Islamiyyah Cilacap melalui kegiatan pengabdian masyarakat akan mengadakan program "Pemberdayaan Kader Posyandu Dalam Upaya Skrining Kehamilan Melalui Pemeriksaan Kehamilan Sederhana di Desa Menganti Kabupaten Cilacap". Program ini dapat dijadikan sebagai salah satu kegiatan unggulan khususnya dalam penerapan bidang keilmuan kebidanan serta sebagai langkah pengabdian kepada masyarakat bagi dosen di perguruan tinggi tersebut.

Adapun kegiatan pengabdian ini yaitu mengadakan kegiatan penyuluhan kesehatan/promosi kesehatan tentang penyebab tidak langsung kematian ibu, melakukan pelatihan ketrampilan melakukan deteksi dini risiko kehamilan dan melakukan skrining kehamilan dengan pemeriksaan kehamilan sederhana (pengukuran LILA, pengukuran kadar $\mathrm{Hb}$, penapisan empat terlalu) oleh kader posyandu kepada ibu hamil. Tempat pelaksanaan dari program ini adalah di Desa Menganti, Kabupaten Cilacap. Tujuan dari kegiatan ini diharapkan dapat meningkatkan pengetahuan dan ketrampilan kader posyandu sehingga mampu melakukan skrining kehamilan melalui pemeriksaan kehamilan sederhana.

\section{MASALAH}

Permasalahan mitra yang ditemukan adalah sebagai berikut :

1) Kurangnya pengetahuan kader posyandu tentang gizi pada ibu hamil

2) Kurangnya pengetahuan kader posyandu tentang deteksi dini faktor risiko kehamilan dalam hal ini adalah empat terlalu

3) Ketidakmampuan melakukan deteksi dini faktor risiko kehamilan dengan pemeriksaan sederhana kehamilan (pengukuran LILA dan pemeriksaan Hb dengan stik).

\section{METODE}

Pengabdian ini dilaksanakan dengan metode: 
1) Berkoordinasi dengan pihak Desa Menganti sebagai tempat pengabdian masyarakat.

2) Pemberian materi tentang masalah gizi pada ibu hamil dan empat terlalu.

3) Demonstrasi cara pengukuran LILA dan pengukuran kadar $\mathrm{Hb}$

4) Pemberian tugas kepada kader posyandu untuk melakukan pemeriksaan kehamilan sederhana pada ibu hamil di lingkungannya dan evaluasi dilakukan seminggu setelah dilakukan pengabdian masyarakat.

Adapun gambaran umum penerapan kegiatan pengabdian kepada masyarakat ini adalah :

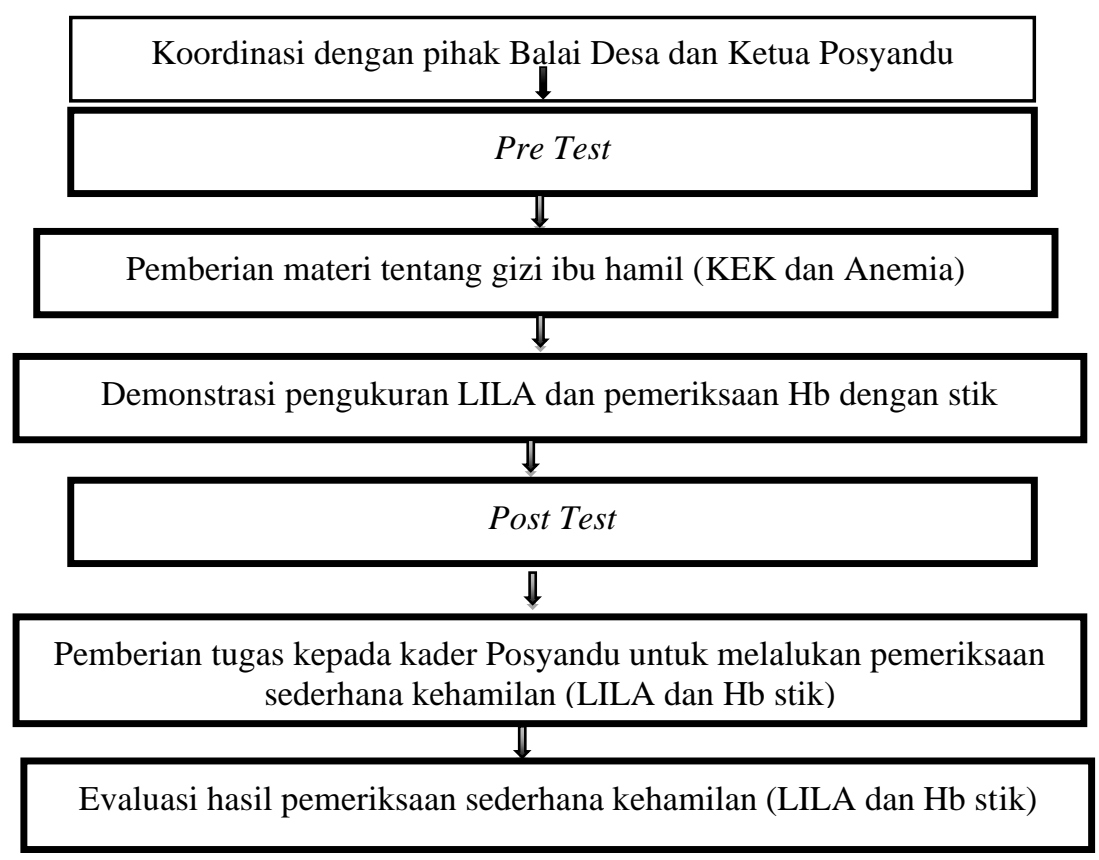

Bagan 1. Alur Kegiatan Pengabdian Kepada Masyarakat

\section{HASIL DAN PEMBAHASAN}

1) Hasil

Pelaksanaan program pengabdian kepada masyarakat terkait Pemberdayaan Kader Posyandu Dalam Upaya Skrining Kehamilan Melalui Pemeriksaan Sederhana di Desa Menganti, Kabupaten Cilacap dilaksanakan pada :

Hari/tanggal : Rabu, 29 Juli 2020

Pukul : $09.00-12.00 \mathrm{WIB}$

Jumlah Peserta $\quad$ : 21 orang

Tempat $\quad$ : Balai Desa Menganti, Kabupaten Cilacap

Hasil kegiatan program pengabdian kepada masyarakat dalam rangka Pemberdayaan Kader Posyandu Dalam Upaya Skrining Kehamilan Melalui Pemeriksaan Kehamilan di Desa 
Menganti, Kabupaten Cilacap dilakukan dengan dua metode yaitu :

1) Pengisian kuesioner pre test tentang pengetahuan masalah gizi selama kehamilan (pengukuran LILA dan anemia) dan empat terlalu oleh kader Posyandu Desa Menganti untuk mengukur pengetahuan. Hasil nilai rata-rata pengetahuan kader adalah 65,9.

2) Metode presentasi tentang materi tentang masalah gizi selama kehamilan (KEK dan anemia) dan empat terlalu yang disampaikan oleh ketua pelaksana pengabdian an Rochany S, S.ST., MPH dibantu oleh anggota kepada kader Desa Menganti, Kabupaten Cilacap

3) Demonstrasi pengukuran LILA dan pemeriksaan Hb dengan stik yang dilakukan oleh tim pengabdian.

4) Pengisian kuesioner post test tentang pengetahuan tentang masalah gizi selama kehamilan (KEK dan anemia) dan empat terlalu oleh kader Posyandu Desa Menganti, Kabupaten Cilacap. Hasil nilai rata-rata pengetahuan kader adalah 97,45.

5) Evaluasi ketrampilan kader dalam melakukan pengukuran LILA dan pemeriksaan $\mathrm{Hb}$ dengan stik. Hasil perwakilan 3 kader Posyandu Desa Menganti, Kabupaten Cilacap dapat melakukan pemeriksaan sederhana tersebut.

6) Evaluasi akhir dilakukan pada tanggal 25 Agustus 2020 jam 10.00 di rumah Kepada Dusun Kelang, Desa Menganti, Kabupaten Cilacap. Evaluasi yang dilakukan adalah ketrampilan salah satu kader dalam melakukan pengukuran LILA dan pemeriksaan $\mathrm{Hb}$ serta penapisan empat terlalu. Evaluasi ini dilakukan pada 6 ibu hamil. Hasil pemeriksaan LILA dan $\mathrm{Hb}$ semua dalam keadaan normal dan untuk penapisan empat terlalu semua hamil termasuk dalam kelompok ibu hamil tidak berisiko. Hasil pemeriksaan pada 6 ibu hamil tersebut kemudian diserahkan kepada Bidan Desa, yang memang pada pelaksanaan evaluasi tersebut Bidan Desa nya sedang melakukan kelas ibu hamil.

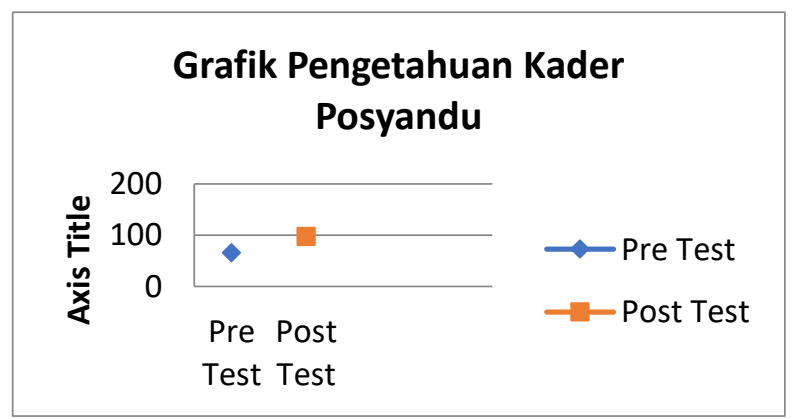

Grafik 1. Pengetahuan Pre Test dan Post Test Kader Posyandu 
Pada grafik di atas dapat dilihat mengenai peningkatan pengetahuan kader posyandu tentang masalah gizi selama kehamilan (KEK dan anemia) dan empat terlalu. Pengetahuan kader posyandu sebelum dilakukan penyuluhan adalah 65,9 dan setelah dilakukan penyuluhan kesehatan menjadi 97,45. Dalam hal ini, penyuluhan kesehatan memberikan manfaat terhadap peningkatan pengetahuan kader posyandu. Hal sesuai dengan (Notoatmodjo. S., 2012) yang menyatakan bahwa penyuluhan adalah kegiatan nonformal dalam rangka mengubah masyarakat menuju keadaan yang lebih baik.

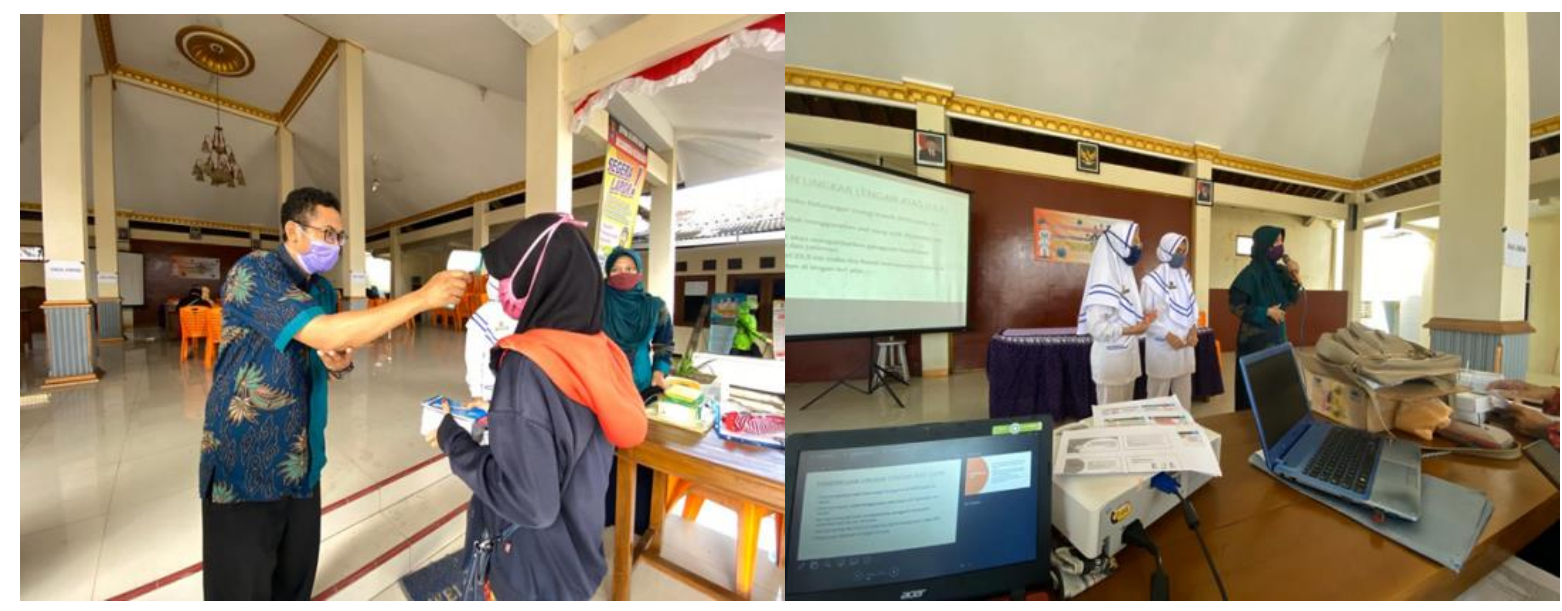

Gambar 1. Protokol Kesehatan

Gambar 2. Pemberian Materi dan Demonstrasi

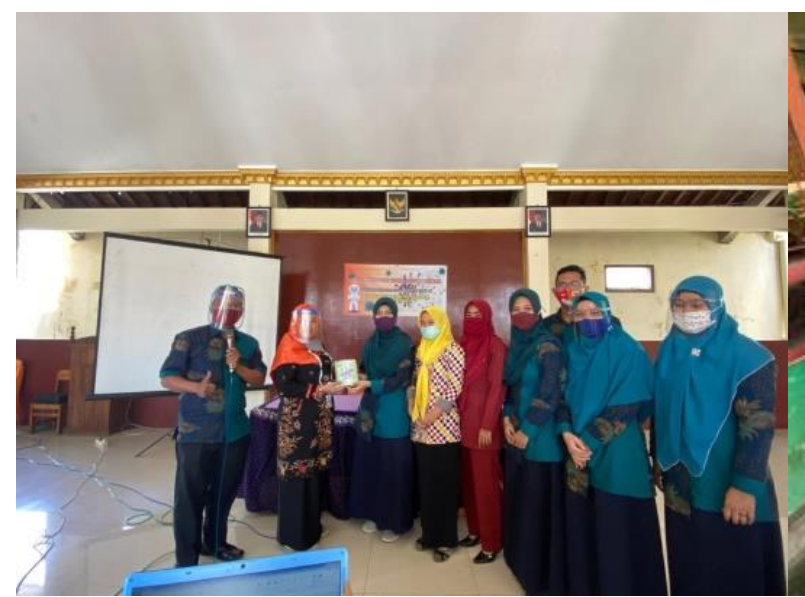

Gambar 3. Pemberian Alat Kesehatan

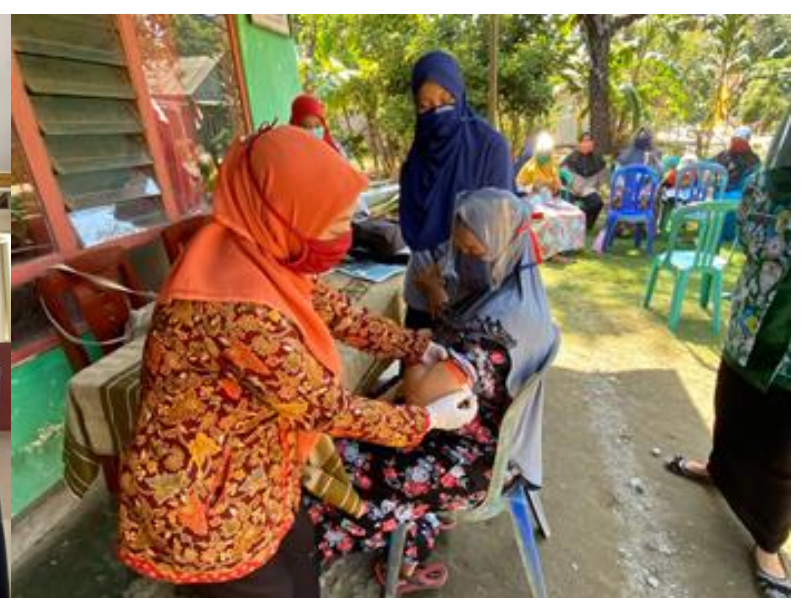

Gambar.4. Pemeriksaan Ibu Hamil

\section{2) Pembahasan}

Rangkaian kegiatan pengabdian dengan tema upaya pemberdayaan kader posyandu dalam upaya skrining kehamilan melalui pemeriksaan kehamilan di Desa Menganti, Kabupaten Cilacap membawa perubahan yang dapat dilihat dengan adanya peningkatan pengetahuan kader posyandu dari sebelum dan sesudah diberikan penyuluhan kesehatan 
tentang masalah gizi selama kehamilan dan empat terlalu. Peserta yang hadir sangan antusias dalam mengikuti kegiatan ini terlebih lagi saat demonstrasi pemeriksaan LILA dan pemeriksaan $\mathrm{Hb}$ dengan stik, karena hal tersebut merupakan hal baru untuk para kader posyandu. Penyuluhan kesehatan tentang masalah gizi selama kehamilan dan empat terlalu menjadikan kader posyandu lebih memahami tentang pentingnya gizi selama kehamilan dan penapisan empat terlalu. Hal ini sejalan dengan penelitian (Solehati, 2018) yang menyatakan bahwa pendidikan kesehatan tentang anemia yang merupakan salah satu masalah gizi selama kehamilan berpengaruh dalam peningkatan pengetahuan kader.

Peningkatan pengetahuan dan ketrampilan kader posyandu dalam melakukan upaya skrining kehamilan dalam hal ini pemeriksaan LILA, pemeriksaan $\mathrm{Hb}$ dan penapisan empat terlalu membawa perubahan yang signifikan terhadap sikap kader posyandu dalam memahami pentingnya gizi selama kehamilan. Apresiasi dan antusias yang ditunjukkan oleh kader posyandu diharapkan menjadi motivasi dan dukungan sosial kepada ibu hamil akan kesadaran pentingnya masalah gizi selama kehamilan dan menjadikan kader posyandu sebagai mitra bidan dalam upaya skrining kehamilan dalam hal ini deteksi dini masalah gizi dengan pemeriksaan sederhana seperti pengukuran LILA, pemeriksaan $\mathrm{Hb}$ dan penapisan empat terlalu. (Idris, 2014) dalam penelitiannya menyatakan bahwa ada hubungan antara pengetahuan, sikap dan motivasi terhadap kinerja kader posyandu. Peran kader posyandu merupakan salah satu ujung tombak keberhasilan dalam rangka penurunan AKI dan AKB, karena kader posyandu merupakan perpanjangan tangan petugas kesehatan yang mampu merangkul dan menjangkau masyarakat secara luas.

Peran kader dalam melakukan upaya skrining kehamilan dengan pemeriksaan kehamilan sederhana merupakan faktor penting dalam peningkatan dukungan sosial masyarakat sehingga dapat meningkatkan kualitas kesehatan ibu hamil. Hal ini sejalan dengan penelitian oleh (Setyoadi, 2013) yang menunjukkan bahwa ada hubungan yang signifikan peran kader dengan tingkat kualitas hidup melalui promosi kesehatan.

\section{KESIMPULAN}

Berdasarkan hasil kegiatan pemberdayaan kader posyandu dalam upaya skrining kehamilan melalui pemeriksaan kehamilan sederhana di Desa Menganti membawa perubahan yang baik dalam memahami tentang masalah gizi selama kehamilan (anemia dan KEK) dan penapisan empat terlalu, hal ini dibuktikan dengan adanya peningkatan pengetahuan kader 
sebelum dan setelah dilakukan penyuluhan. Kader posyandu di Desa Menganti mampu melakukan pemeriksaan kehamilan sederhana dengan menggunakan alat yang diberikan oleh tim pengabdian STIKES Al Irsyad Al Islamiyyah Cilacap (pengukuran LILA, pemeriksaan $\mathrm{Hb}$ dan penapisan empat terlalu) kepada 6 ibu hamil. Hasil dari 6 ibu hamil yang dilakukan pemeriksaan LILA dan $\mathrm{Hb}$ dalam keadaan normal dan tidak termasuk kelompok empat terlalu.

\section{DAFTAR PUSTAKA}

Achadi, L. E. (2019). Kematian Maternal dan Neonatal di Indonesia.

Adriani M dan Wirjatmadi B. (2016). Peranan Gizi Dalam Siklus Kehidupan. Prenadamedia.

Detik Health. (2019). 4 Terlalu dan 3 Terlambat Sumbang Angka Kematian Ibu. Detikhealth.Com.

Idris, F. N. (2014). Hubungan Pengetahuan, Sikap dan Motivasi Kader Dengan Kinerja Kader Posyandu Di Wilayah Kerja Puskesmas Tilango Kecamatan Tilango Kabupaten Gorontalo.

Jawa Pos. (2019). Angka Kematian Ibu dan Bayi Di Jawa Tengah Kian Berkurang. Jawa Pos.Com.

Kementrian Kesehatan Republik Indonesia. (2015). Profil Kesehatan Indonesia. Kementrian Kesehatan Republik Indonesia. Vol.51. https://doi.org/https://doi.org/10.1037/00223514.51.6.1173

Krisnadi, S. R. (2014). Prenatal Care (PNC) Yang Berkualitas. In H. G. Setiabidawan(Ed.). Fakultas Kedokteran Universitas Padjajaran.

Notoatmodjo. S. (2012). Promosi Kesehatan dan Perilaku Kesehatan. Rineka Cipta.

Riset Kesehatan Dasar (Riskesdas). (2018). Badan Penelitian dan Pengembangan Kesehatan Kementrian RI tahun 2018.

Setyoadi, et al. (2013). Hubungan Peran Kader Kesehatan Dengan Tingkat Kualitas Hidup Lanjut Usia. Jurnal Ilmu Keperawatan Universitas Brawijaya, Vol. 1(No.2.).

Solehati, et al. (2018). Pengaruh Pendidikan Kesehatan Terhadap Pengetahuan Deteksi Dini Dan Pencegahan Anemia Dalam Upaya Menurunkan AKI Pada Kader Posyandu. Nursing Journal Tempic, Vol. 4(No.1). 